\title{
Key factors influencing the sale of bulls in livestock auctions
}

Giovana Tagliari Evangelista ${ }^{\text {a }}$

Jusecléia Ferreira Lopes ${ }^{a^{*}}$

Giordano Bruno Fornar ${ }^{\mathrm{a}}$

Ricardo Pedroso Oaigen ${ }^{b}$

Thaís Lopes Gonçalves ${ }^{b}$

Tamara Esteves de Oliveira ${ }^{a}$

Luís Kluwe de Aguiar $^{c}$

Júlio Otávio Jardim Barcellos a

${ }^{a}$ Universidade Federal do Rio Grande do Sul, Departamento de Zootecnia. Rio Grande do Sul. Brasil.

${ }^{\mathrm{b}}$ Universidade Federal do Pampa. Rio Grande do Sul. Brasil.

${ }^{\mathrm{c}}$ Harper Adams University, Department of Food Science. Newport, United Kingdom.

* Corresponding author: jussiferreiralopes@gmail.com

\begin{abstract}
:
This research determines which factors most influence the purchase price of bulls in livestock auctions in the State of Rio Grande do Sul, Southern Brazil. Hence, 760 beef bulls sold in eleven different auctions between August and November 2013 were analysed. The data consists of: breed, muscularity (MUSC), frame (FRAME), body condition score (BCS), scrotal circumference (SC) and body weight (BW). Other data such as the animal entry order and the purchase price of the bulls was collected during the auction. A linear generalized model was used to evaluate the interaction of each variable with the purchase price of the bulls. An ANOVA with Tukey post-hoc was used to compare the differences between the categories that influenced the purchase price of bulls and were realized in the software SPSS 20.0. All breeds presented declining prices
\end{abstract}


from the first to the second entry order and increasing purchase prices from the order third to forth. Bulls with large frame received higher purchase prices independent of the auction order, except for the second order of entry, in which medium and small animals were more valued. Angus bulls obtained the highest prices in relation to the breeds Brangus and Hereford. The frame and breed constituted the main phenotypic characteristics that influence in price. In addition, the order of entry of bulls in the ring influence the purchase price.

Key words: Breed, Bulls, Livestock Auction, Marketing, Price.

Received: 08/09/2017

Accepted: 13/07/2018

\section{Introduction}

Brazilian cow-calf systems typically consist of bulls, breeding cows, heifers and calves. In these systems, the number of bulls account for about 3 to $5 \%$ of the animals ${ }^{(1)}$, and approximately $25 \%$ are replaced annually, this constituting a significant component in the production $\operatorname{cost}^{(2)}$. This bull for use, it is usually provided by producers of pure breeds, which should know the value of genetic and phenotypic characteristics that affect the selling price ${ }^{(3)}$. Furthermore, as profit margins in cow-calf systems tend to be narrow, to increase profitability farmers must aim at breeding animals which return higher productivity whilst meeting market expectations ${ }^{(4,5)}$.

Nevertheless, several variables affect bulls selling price, such as the breed, muscularity, frame, age and scrotal circumference ${ }^{(3,6)}$, but not all livestock buyers are looking for the same characteristics. Often, those features that would best meet the buyer's requirements are overlooked in detriment of others such as animal conformation ${ }^{(7,8)}$, and should be analysed and understand to develop rational marketing strategies.

Moreover, since Brazilian bulls are usually traded at auctions, investigating the extent that each factor might influence and bulls selling prices could increase the competitiveness of the sector. However, price formation is complex and influenced by endogenous and exogenous factors such as supply and demand forces, stocks carried over, farmers' decision-making and the buyers' behaviour during purchase. Therefore, since qualitative and quantitative characteristics influence the sale of the animals ${ }^{(9)}$, this 
research analyses livestock auction arrangements and the most relevant animal features perceived by bull buyers, which affect livestock auction prices.

\section{Material and methods}

Data from the sale of 760 bulls was collected from eleven different livestock auctions held in six towns (Alegrete, 1; Dom Pedrito, 3; Esteio, 1; Santa Vitória do Palmar, 1; Santana do Livramento, 3, and Uruguaiana, 2) in the state of Rio Grande do Sul, Brazil, from August to November 2013. The livestock auctions were held annually as part of the traditional bulls' sale calendar. The auctions were conducted by different auctioneering companies and were typically located at agricultural fairs. However, in two cases the auctions took place at farms (Uruguaiana, 1; Dom Pedrito,1). All bulls were certified by the respective breeder's associations and were offered between 2 to 3 ys of age.

Following established literature on the matter, a standard form was devised to collect relevant information on the animals' characteristics which could influence buyers' decision-making. The attributes collected consisted of the breed, muscularity score (MUSC), frame score (FRAME) and body condition score (BCS) of the bulls. The breeds that were analysed in the auction were: Angus, Brangus, Hereford and Braford.

The Angus breed originated in Scotland and development in Brazil occurred in different regions, especially the cattle herds in southern Brazil. It is a breed of moderate size, naturally polled and can be black or red in colour ${ }^{(10)}$. The Brangus is formed by Zebu with Angus, and thus has the predominant characteristics in Angus, such as carcass quality, pigmentation, fertility and precocity; with those of Zebu, which are adaptability and rusticity ${ }^{(11)}$.

The Hereford breed originates from the County of Hereford in England. The breed is coloured dark red to red-yellow, with a white face, crest, dewlap, and underline. The animals can be polled or with short thick horns that typically curve down at the sides of the head ${ }^{(12)}$. The origin of the Braford breed was by a cross between a Hereford x Brahman or Hereford x Nelore breeds. Currently, the Braford breed has fertility, maternal ability, precocity and meat quality of Hereford with the ability to adapt to the tropics, rusticity and carcass yield of zebu ${ }^{(12)}$.

As for FRAME, scores from 1 to 3 were given according to the height measured from animals' hip as proposed and adapted from the works of the Beef Improvement Federation $^{(13)}$. FRAME 1 represented heights from 104 to $114 \mathrm{~cm}$, typically of smaller biotypes; FRAME 2 varied from 119 to $129 \mathrm{~cm}$, representing biotypes of average height; and FRAME 3 were typical of animals of large biotype. 
Regarding the MUSC, the bulls were classified according the scores $1-3$, where MUSC 1 represent those of concave muscular profile, narrow width between the hind legs, prominent hip bone and tapered thigh; MUSC 2 was typical of animals of average muscularity, muscular profile less convex, hip bones slightly prominent; and MUSC 3 were those animals of better muscularity, convex muscular profile, large width between the hind legs, well rounded top line and thicker thigh.

As for the BCS of 1 to 5 were given based and adapted ${ }^{(14)}$. Those showing a BCS 1 were typically of low muscularity, very lean, and whose ribs were visible; BCS 2 represented lean bulls with low rib fat cover which also presented protruding hip bones; bulls with BCS 3 score had moderate muscular cover whose ribs were practically covered; BCS 4 represented bulls of good muscular cover and which had some fat cover; and BCS 5 were typical of bulls with excess fat cover at the tail fold and ribs.

Information available from sales catalogues published by the livestock auctioneers regarding general sale's conditions (payment terms which could attract a discount for payments paid at sight or in instalments varying from up to 15 or $20 \mathrm{mo}$ ); body weight (BW) and scrotal circumference (SC) were used. The bulls were sold following a typical English style auction where the bids were made until the price reached its maximum. To analyse the effect of entry order (ORDER) on the selling price at each auction, the animals were grouped into four stages consisting of $1^{\text {st }}$ quarter (batch 1 to 9 ), $2^{\text {nd }}$ quarter (10 to 17 ), $3^{\text {rd }}$ quarter (18 to 29 ) and $4^{\text {th }}$ quarter (remaining batches). The ORDER was registered against the animals' initial and selling price and the likely sale terms.

For the evaluation of the equivalent fat cattle (EFC), the price of one bull sold in the auction was divided by the price of bullocks' in the same period (equivalent price obtained in 2013) ${ }^{(15)}$, and with that was determined the number of bullocks' (EFC=450 $\mathrm{kg}$ ) that is equivalent to the price of one bull.

Using SPSS software version 20.0, statistical analysis of the data, including frequency, mean, median, maximum and minimum values, standard deviation of price. A linear generalized model was used to evaluate the interaction of each variable with the purchase price of the bulls, and the best model is presented by the Equation 1:

\section{in which:}

$$
\mathrm{P}=\beta+\varphi+\omega+\psi+\phi+\beta^{*} \psi+\varphi^{*} \psi+\omega^{*} \psi+\phi^{*} \psi+\mathrm{e}
$$

$\mathbf{P}=$ purchase price;

$\boldsymbol{\beta}=$ breed;

$\varphi=$ frame;

$\omega=$ muscularity;

$\boldsymbol{\psi}=$ entry order;

$\phi=$ body condition score;

$\mathbf{e}=$ experimental error. 
An ANOVA with Tukey post-hoc was used to compare the differences between the categories that influenced the purchase price of bulls. All analysis considered a $95 \%$ level of significance and were realized in the SPSS 20.0.

\section{Results}

The average bulls' market liquidity in the auctions was approximately $90 \%$, and the purchase price presented a great price range. The purchase price ranged between $\$ 1,645.00$ and $\$ 14,473.00$ with an average price of 4,092.00 dollars (Figure 1). Usually, sellers and buyers referred to the equivalent fat cattle parameter, in this research, the EFC ranged from 2.5 to 6.4 bullocks.

Figure 1: Frequency of bulls sold in auctions in Rio Grande do Sul according to price intervals

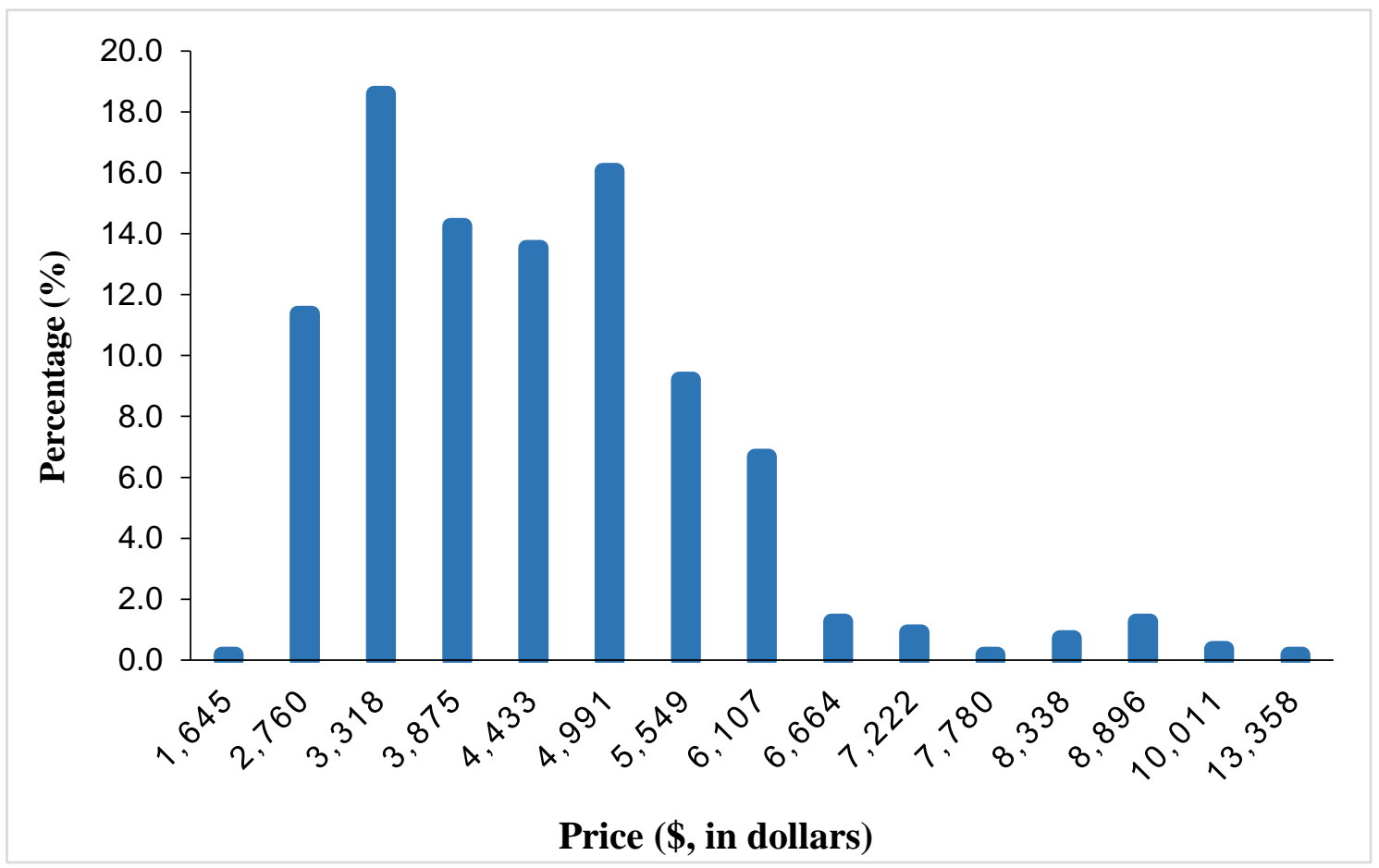

There was no association between weight and price; in addition, scrotal circumference did not this related to the price. As for the characteristics evaluated subjectively, such as muscularity and body condition score were also not associated with the final price of the bulls at auctions. In this research, no bull presented a BCS below three (average 3.88) and 
bulls with light muscularity were to be Angus and Brangus with 63.2 and $31.6 \%$ light muscularity respectively. Only $2.7 \%$ of the animals sampled exhibited a light muscularity whilst 85.5 and $11.6 \%$ of the sample presented a moderate and strong muscularity respectively. Moreover, all the lighter animals were sold during one auction location only, thus contributing to the outliner effect as the selling prices of such an auction might have been higher than in other auction locations.

However, other variables also influenced the bulls market ${ }^{(6)}$ as it was seen, in the best model representing the factors influencing the purchase price of bulls in auctions. It was found that the price in 2013 was influenced by the breed and frames of bulls, as well as the entry order of the animals in the auction. The purchase price was also influenced by the interactions of breed and entry order and the interaction of frame and entry order.

The price payed for which breed of bull differ between the entry orders. All breeds presented declining prices from the first to the second entry order and increasing purchase prices from the order third to forth. However, from the second to third order Angus and Brangus increased while Hereford and Braford decreased in the purchase price (Figure 2).

Figure 2: Effect of the interactions between breed and entry order over the purchase price of bulls sold in auctions in the state of Rio Grande do Sul, Southern Brazil

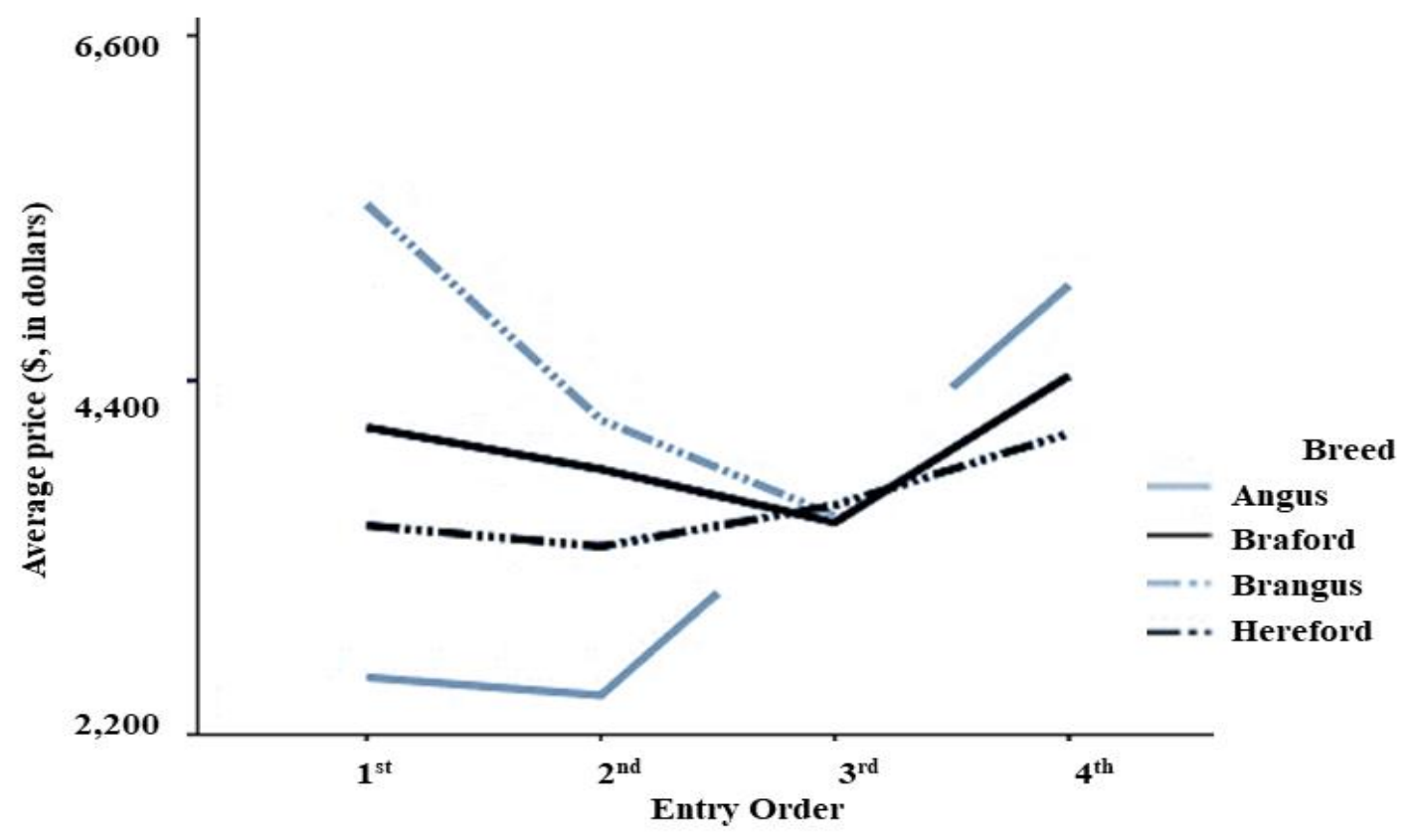

Large bulls received higher purchase prices in all orders, except in for the second order of entry, in which medium and small animals were more valued (Figure 3). The purchase price in the fourth entry order was higher than in all the others, and there was also a difference between the first and third entry orders, in which the latter presented the lowest 
prices (Figure 4). The purchase price of smaller bulls was lower than that of mediumsized animals, and the price of the latter did not differ from that of larger bulls (Figure 5).

Figure 3: Effect of the interaction between frame and entry order over the purchase price of bulls sold in auctions in the state of Rio Grande do Sul, Southern Brazil

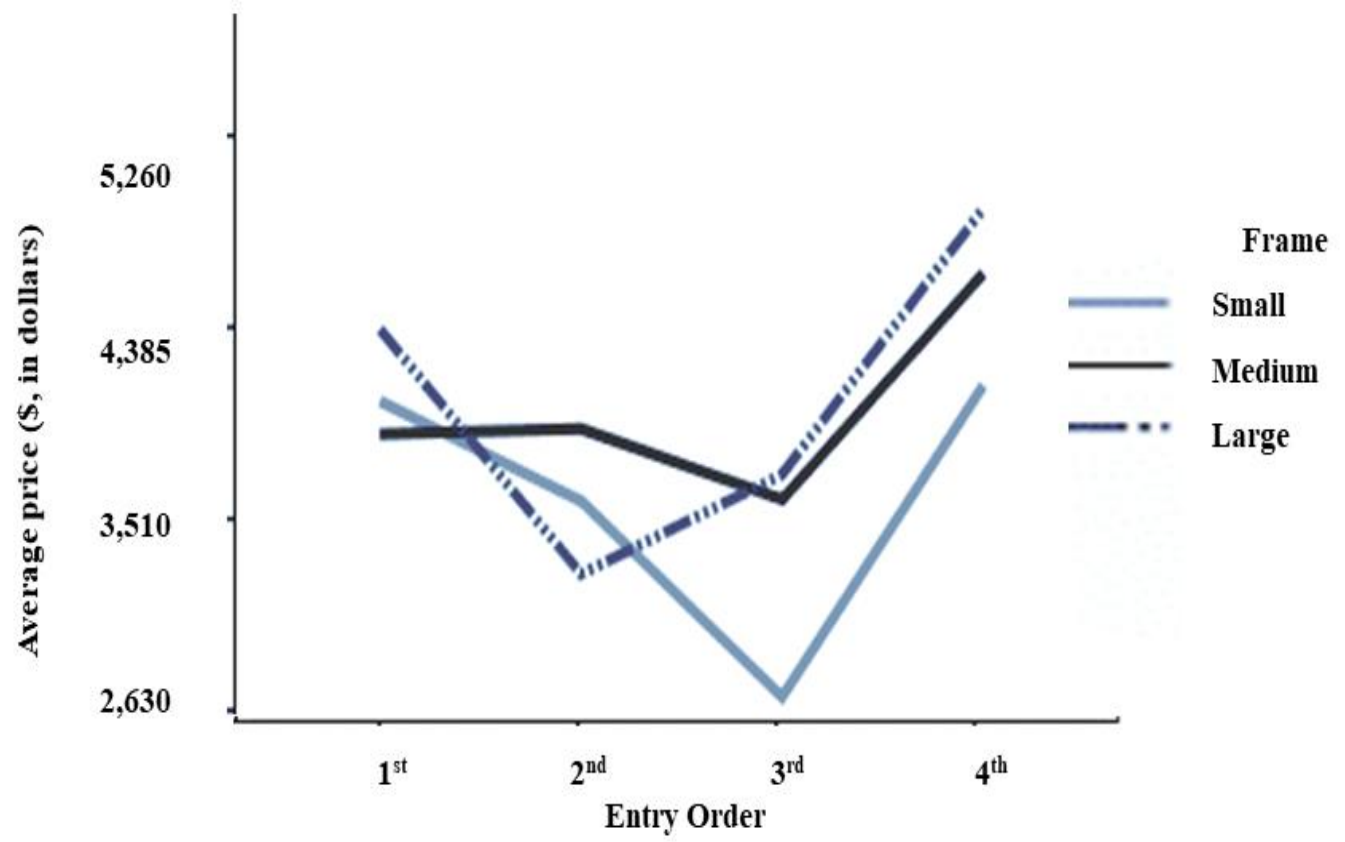

Figure 4: Effect of the entry order the purchase price of bulls sold in auctions in the state of Rio Grande do Sul, Southern Brazil

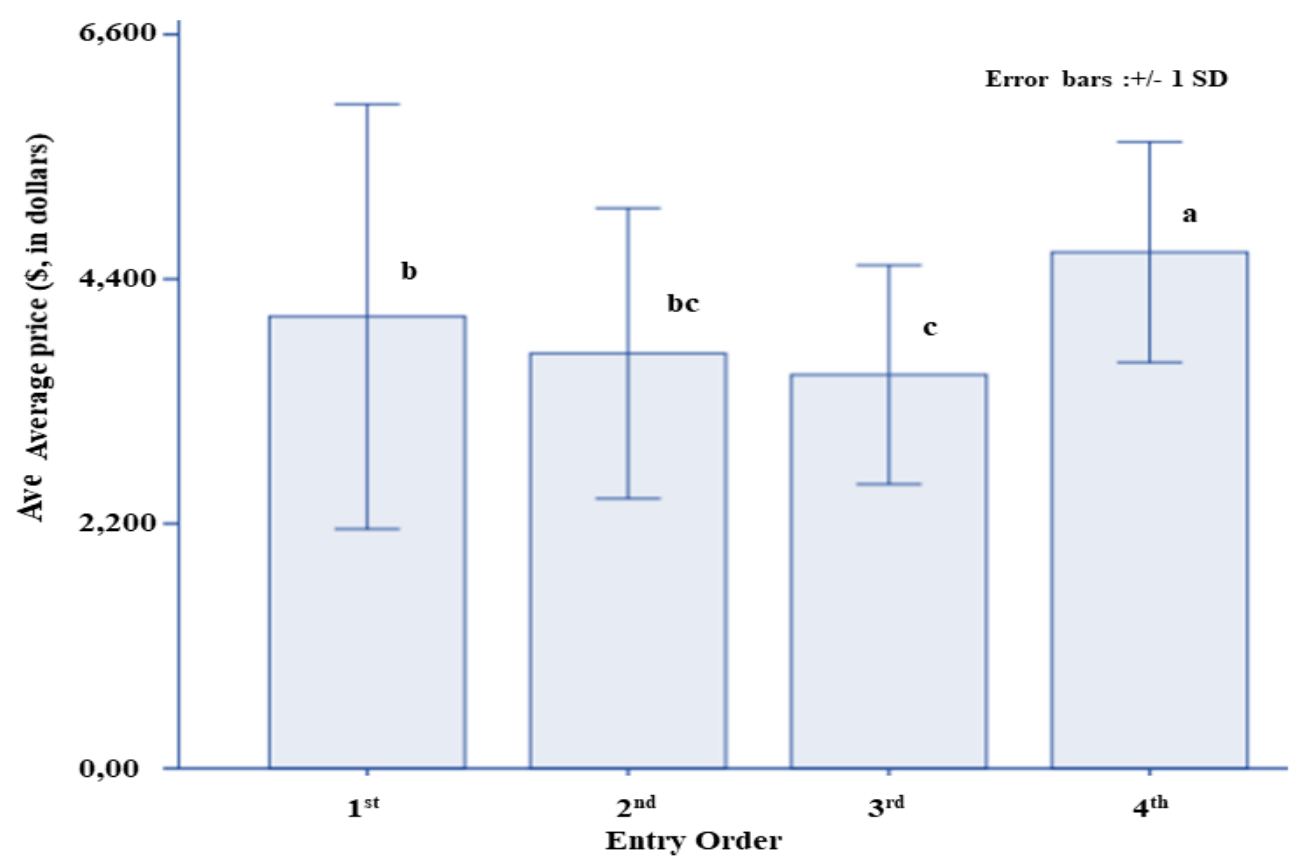


Figure 5: Effect of the frame over the purchase price of bulls sold in auctions in the state of Rio Grande do Sul, Southern Brazil

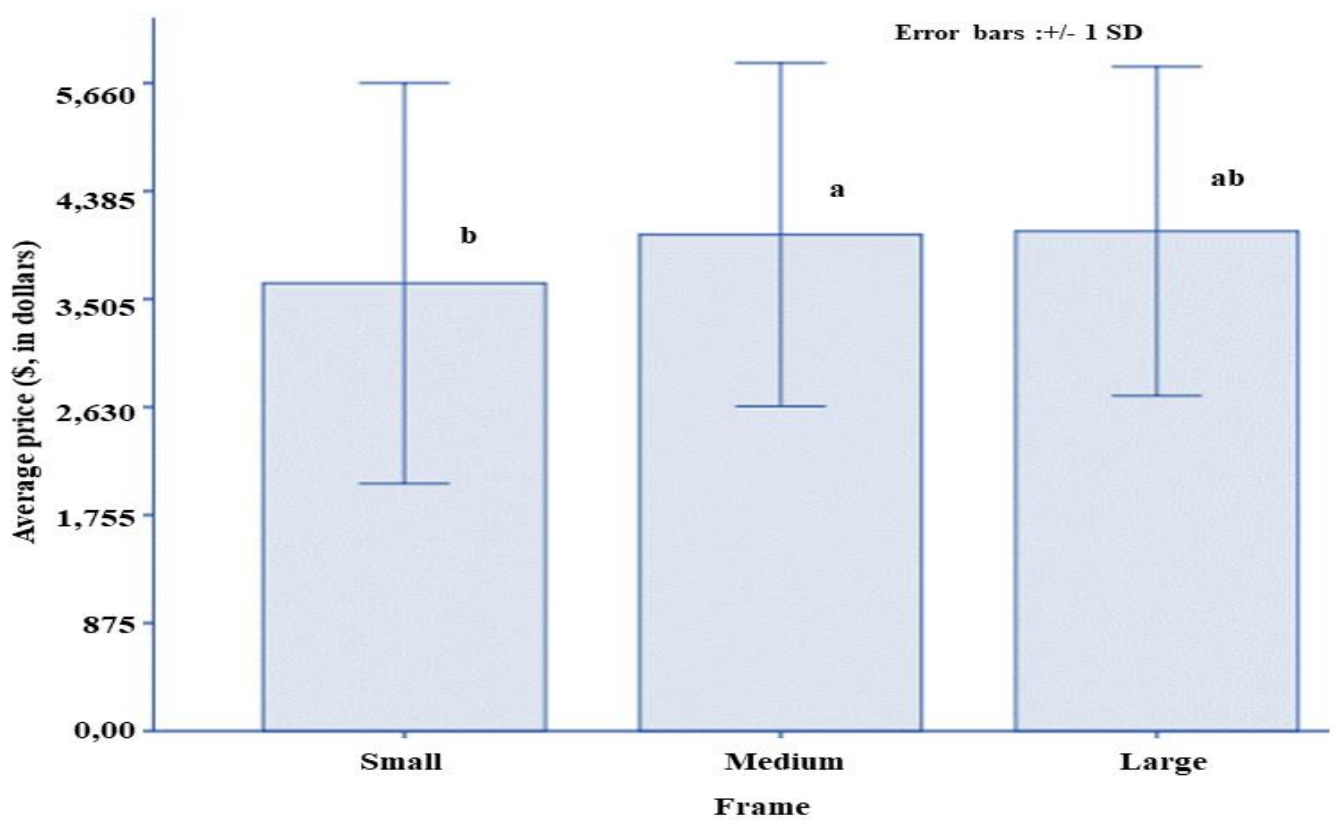

In the present study it was verified that Angus bulls obtained the highest prices in relation to the breeds Brangus and Hereford, although the supply of Angus animals was only $15 \%$ (Figure 6). However, this may reflect the number of auctions, since one of these is on the market for around $60 \mathrm{yr}$. Braford and Hereford bulls were marketed in 9 and 10 auctions, respectively. This must have contributed to the fact that they received the lowest prices.

Figure 6. Effect of the breed over the purchase price of bulls sold in auctions in the state of Rio Grande do Sul, Southern Brazil

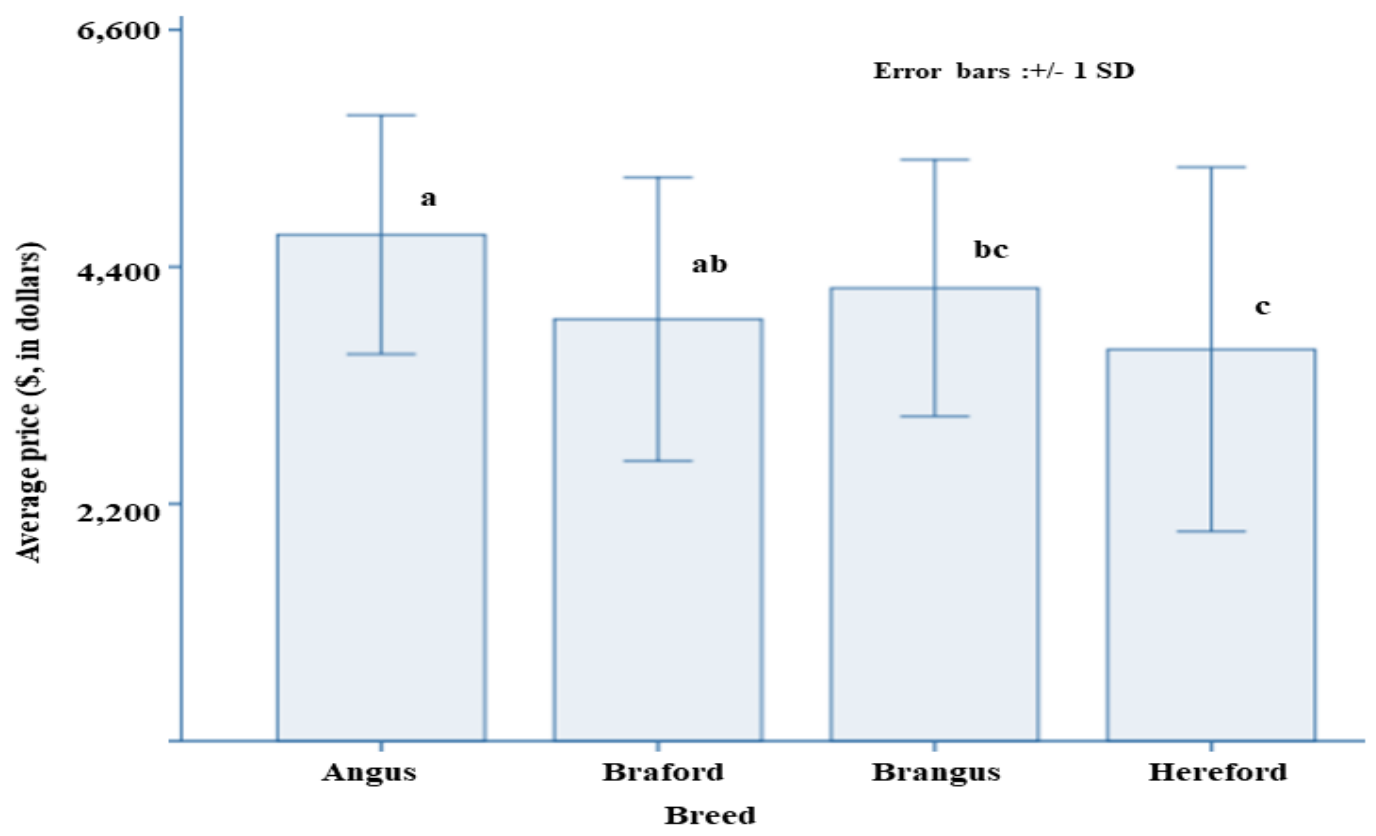




\section{Discussion}

The high liquidity in the auctions could be attributed to the high demand for bulls in the year of the study (2013). That could also reflect the consolidation in auction houses, which have been marketing for at least $10 \mathrm{yr}$. Moreover, the reputation of bull breeders historically can exercise some influence in the buyer decisions ${ }^{(3,6,16)}$. In addition, the state of Rio Grande do Sul is a major supplier of bulls of European and synthetic breeds to the other states of Brazil.

Moreover, in general, the higher the price, the lower the frequency of animals sold, because bulls with higher phenotypic characteristics tend to require greater care regarding maintenance, increasing their future cost in the farm. This is more concerning since most bulls are sold to typically commercial livestock farmers ${ }^{(17)}$. The equivalent fat cattle (EFC) found in this research indicated that farmers engaged in the breeding bulls attended the needs of different cattle farmers. However, the large majority of bulls sold aimed to meet the demand of commercial herds, as only $10 \%$ of the bulls sold at equivalent fat cattle (EFC) 6.4 or higher. This asymmetric price variation is an indicative of product differentiation, as bull buyers tended to favour animals whose phenotypical characteristics are not directly proportional to the observable parameters ${ }^{(18)}$.

Despite the lack of association between weight and price in this research, this has been found in previous researches ${ }^{(19,20,21)}$, possibly because weight influences bulls' appearance and could infer a likely weight gain potential, a desirable feature for breeders $^{(17)}$. However, that cannot be assessed only by visual observation, and too much an emphasis on weight at the sale can be detrimental to younger bulls which are lighter, but might be genetically superior. Furthermore, overfeeding also could produce heavier animals that can result in mounting difficulty and low semen quality ${ }^{(22)}$. Therefore, the potential genetic contribution that a heavier bull could have in a herd may be impaired if these animals are not healthy enough by being unable to search for females in heat and reproduce. Since fat bulls with excess fat deposited at the base of the tail need to lose a lot of weight to be used to work in the field.

Accordingly, the scrotal circumference, which was not related to price, is another important phenotypical characteristic usually publicised by catalogues, and one of the most important predictor of fertility and precocity in bulls ${ }^{(19,23)}$. However, should SC be obtained during the sales, other environmental effects could be masking the true bull's potential, as overfeeding.

Despite being a favourable characteristic in beef herds, muscularity was not related to higher prices, which could be explained by the low representativeness of the sample, since only $2.7 \%$ exhibited light muscularity, whilst $85.5 \%$ and $11.6 \%$ presented moderate and strong muscularity, respectively. Moreover, all the lighter animals were sold during one 
auction, contributing to the outliner effect as the purchase prices of such an auction. Nevertheless, muscularity is an important phenotypic trait as it influences buyer's evaluation at the purchase, since it is associated to future meat production. Hence, the selection for muscularity should be optimized, not maximized to avoid birth difficulties $^{(24)}$.

Body condition score indicates an adequate nutritional and it is an important visual feature for buyers. Hence, since the high nutritional level may exacerbate bulls' physical qualities, it was expected that buyers favoured bulls with larger BCS, but this feature did not influence the purchase price.

The purchase price was higher in the first and last $\left(4^{\text {th }}\right)$ entries, and the latter presented the highest prices. The reduction in purchase price as the entry order progresses gets to the middle of the auction, second and third quarters, could be attributed to a decreased interest by the buyers, as they could have their needs fulfilled at the beginning of the auction. Nevertheless, the reduction in values according to the entry order can be also explained by a decrease of the relative quality of bulls. Moreover, as the auction progresses the weight of the animals entering the ring diminishes, also reflecting in a lower purchase price.

Nevertheless, the highest prices were seen in the last quarter of the auction, mainly for Angus bulls, which also presented higher prices at the end of the auction, as well as Braford and Hereford bulls. The lack of Brangus bulls at the final quarter and of Angus at the third quarter could be a major influence in this analysis.

Moreover, small animals received lower purchase prices except in the second quarter, probably because buyers believed that larger bulls could be more efficient in breeding, presenting a lower risk. However, in some breeds, such as Angus, Charolaise, Simmental and Polled Hereford, the frame of bulls increased the purchase price, especially in the $\mathrm{USA}^{(25,26)}$, as seen in the calf market ${ }^{(27)}$. Therefore, the removal of extremes (small and large animals) can be helpful to standardize the herd.

For breeds, Angus bulls attracted higher prices than Hereford and Brangus bulls, which was expected as it was the results of previews studies in the USA ${ }^{(3,20)}$. Despite the supply of Angus bulls of only $15 \%$, that did not negatively affect the purchase price. In addition, the small share of Angus sales derived from two auction locations, but one auction event is very traditional and has been taking place in the same site for over $60 \mathrm{yr}$. The tradition and reputation of the auctions' events can exercise a positive effect on the price. Moreover, Angus and Brangus were sold only in two traditional events (Uruguaiana and Dom Pedrito).

In addition, the different prices between breeds, depended on factors involving buyers' personal preference, soil and climate conditions, market trends and supply/demand relationships. Despite most Brazilian cattle is of zebu herd, the Southern latitude present overall different environmental characteristics with lower average temperatures and natural pastures (pampa grassland). Hence, the widespread use of European breeds 
(Angus and Hereford) and commercial synthetic breeds (Braford and Brangus) is evidence of how well adapted the cattle is to those conditions. The value of a breed per se reflects the commercial circumstances and the characteristics of the auctions (e.g. time to market). Besides the characteristics of the bulls, there are other factors related to the auction system that influence the formation of bull's purchase price. However, for more efficient results in the production, actual production weights (birth, weaning, and yearling weight), and production expected progeny differences (EPD's) (birth, weaning, and yearling) must be considered.

\section{Conclusions and implications}

The bulls' purchase price in livestock auction cannot be determine by only one variable, but the frame and breed constitute the main phenotypic characteristics that influence in price. In addition, the order of entry of bulls in the ring influence the purchase price. These results may be useful to both sellers and buyers of bulls, who need to plan for their purchases and investment. A better understanding of the variables in a bull that would most affect productivity would be a useful instrument to for the purpose of efficient allocation of resources, ensuring liquidity for stocks and possibly a better margin in marketing. In addition, the supply of bulls could be planned according to the expected demand and product carcase specifications.

\section{Literature cited:}

1. Menegassi SRO, Barcellos JOJ, Lampert VDN, Borges JBS, Peripolli V. Bioeconomic impact of bull breeding soundness examination in cow-calf systems. Rev Bras Zootec 2011;40(2):441-447.

2. Barcellos JOJ. Aspectos práticos e mercadológicos que devem pautar a decisão na comercialização de um touro. In: Barcellos JOJ, et al. editors. Bovinocultura de corte: cadeia produtiva \& sistemas de produção. Rio Grande do Sul, Brasil: Agrolivros; 2011:65-69.

3. Dhuyvetter KC, Schroeder TC, Simms DD, Bolze Jr RP, Geske J. Determinants of purebred beef bull price differentials. J Agr Resource Econ 1996;21(2):396-410.

4. Barcellos JOJ, Oiagen RP. Cadeia produtiva da carne bovina e os sistemas de produção na bovinocultura de corte. In: Oiagen RP, et al. editors. Gestão na bovinocultura de corte. Rio Grande do Sul, Brasil: Agrolivros; 2014:21-41. 
5. Thomas M, Hersom M. Considerations for selecting a bull. AN218, one of a series of the Animal Sciences Department, UF/IFAS, 2009. https://edis.ifas.ufl.edu/an218. Accessed Aug 5, 2017.

6. Jones R, Turner T, Dhuyvetter KC, Marsh TL. Estimating the economic value of specific characteristics associated with Angus bulls sold at auction. J Agric Appl Econ 2008;40(1):315-333.

7. Estigarribia AFL, Ortiz CDP. Producer's profile upgrade, technological level and criteria for choosing bulls in Presidente Hayes, Paraguai. FAZU 2011;2(8):172-176.

8. Simms DD, Geske JM, Bolze RP. Commercial cattle producers: bull selection criteria. Agricultural Experiment Station, USA: Kansas State University, 1994;704:56-59.

9. Christofari LF, Barcellos JOJ, Costa ECD, Oaigen RP, Braccini-Neto J, Grecellé RA. Tendency in the commercialization of calves in Rio Grande do Sul related to your genetic characteristics. Rev Bras Zootec 2008;37(1):171-176.

10. Associação Brasileira de Angus (ABA). Manual do Criador. 2013. http://angus.org.br/wp-content/uploads/2018/04/Manual-do-Criador_WEB.pdf Accessed May 12, 2017.

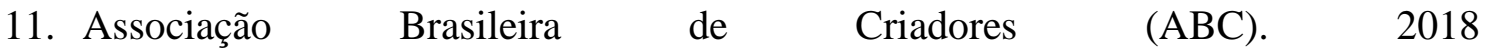
http://www.newsprime.com.br/abccriadores/Racas.aspx Accessed May 10, 2017.

12. Associação Brasileira de Hereford e Braford (ABHB), 2015. http://www.abhb.com.br/Braford/Braford/ Accessed May 12, 2017.

13. Beef Improvement Federation (BIF). Guidelines for uniform beef improvement programs. 5th ed. Beef Improvement Federation, USA: North Carolina State University. 1986;98.

14. Lowman BG, Scott N, Somerville S. Condition scoring beef cattle. Edingburgh: East of Scotland College of Agriculture; 1976.

15. Agrolink Quotations: cattle. 2013. http://www.agrolink.com.br/cotacoes/historico/rs/boi-gordo-kg-vivo-1kg. Accessed Aug 22, 2016.

16. Commer M, Couvilllon WC, Herndon CW, Brown CJ, Getz WR. The effects of promotion in price determination of beef bulls. Prof Anim Sci 1990;6(1):5-10.

17. Dhuyvetter KC, Turner TK, Marston T, Jones R. Factors influencing the selling prices of purebred Angus bulls. Agr Exp Sta Coop Ext Serv, USA: Kansas State University; 2004;16.

18. Bekkerman A, Brester GW, McDonald TJ. A semiparametric approach to analyzing differentiated agricultural products. J Agr Appl Econ 2013;45(1):79-94. 
19. Walburger AM. Estimating the implicit prices of beef cattle attributes: a case from Alberta. Can J Agr Econ 2002;50(2):135-149.

20. Irsik M, House A, Shuffitt M, Shearer J. Factors affecting the sale price of bulls consigned to a graded sale. Bovine Practitioner 2008;42(1):10-16.

21. Marks ML, Parish JA, Smith T, Vann RC, Riley JM. Historical price relationships to performance characteristics and genetic merit of bulls sold in Mississippi Beef Cattle Improvement Association and Hinds Community College Bull Test Sales. Anim and Dairy Sci Ann Rep. Mississippi State University, USA. 2012.

22. Menegassi SRO, Barcellos JOJ, Fornari GB, Canellas LC, Oliveira TE, Soares JCR. Manual de boas práticas para o manejo de touros. $4^{\text {th }}$ ed., Rio Grande do Sul, Brasil. 2015.

23. Menegassi SRO, Pereira GR, Lopes FG, Rocha MK. Exame andrológico. In: Menegassi SRO, Barcellos JOJ editors. Aspectos reprodutivos do touro: teoria e prática. Guaíba, Brasil:Agrolivros; 2015:45-103.

24. Barham B. Bull selection and management guide. Division of Agriculture, USA: University of Arkansas, 2011;39.

25. Atkinson R, Sanders DR, Jones K, Altman IJ. An evaluation of purebred bull pricing: Implications for beef herd management. J Am Soc Farm Man Rural Appr 2010;73:235-243.

26. Mc Hugh N, Fahey AG, Evans RD, Berry DP. Factors associated with selling price of cattle at livestock marts. Animal 2010;4(8):1378-1389.

27. Barham BL, Troxel TR. Factors affecting the selling price of feeder cattle sold at Arkansas Livestock auctions in 2005. J Anim Sci 2007;85:3434-3441. 